\title{
Nutrient Content in Grain and Straw of Different Wheat Genotypes as Affected by Moisture Stress
}

\author{
Aradhna Kumari ${ }^{1}$, R.K. Sairam ${ }^{2}$ and Santosh Kumar Singh ${ }^{3 *}$
}

${ }^{1}$ Section of Plant Physiology, College of Agriculture, Near sub jail, Jawaharlal Nehru Krishi

Vishwa Vidyalaya, Ganj Basoda, M.P., India 464221

${ }^{2}$ Division of Plant Physiology, Indian Agricultural Research Institute, Pusa, New Delhi 110012, India

${ }^{3}$ Department of Soil Science, DRPCAU, Pusa, Samastipur, Bihar 464221, India

*Corresponding author

\section{Keywords \\ Drought stress, Macro nutrient, Micro nutrient, Moisture stress, Wheat \\ Article Info \\ Accepted: \\ 15 January 2019 \\ Available Online: \\ 10 February 2019}

\begin{abstract}
A B S T R A C T
Macronutrient specially $\mathrm{K}$ and micronutrient malnutrition, and particularly deficiency in zinc $(\mathrm{Zn})$, iron $(\mathrm{Fe})$ and manganese $(\mathrm{Mn})$, afflicts over three billion people worldwide. A pot culture experiment was conducted to study the effect of water stress on potassium and some micronutrient accumulation in straw and grains of wheat genotypes. Eight wheat genotypes were grown, 4 tolerant and 4 susceptible against water stress for the experiment. Moisture stress treatment to plants was given at anthesis through withdrawal of water. Soil moisture status of pots subjected to stress treatment was maintained throughout the grain growth period. Schedule routine of irrigation was practiced for control plants throughout the crop growth period. Moisture stress caused changes in nutrient balance of the plants. K, $\mathrm{Zn}, \mathrm{Fe}$ and $\mathrm{Mn}$ concentration were measured both in straw and grain under control and water stress condition at the time of harvesting. Harvest index and 1000 grain weight were also recorded. Mean reduction in harvest index and test weight (1000 grain weight) of seeds was noted in all the genotypes. However, in tolerant cultivars very little reduction was observed as compared to susceptible genotypes. Concentration of K, Zn, Fe and Mn were found more in straw compared to grain under both control and water stress condition. Contents of Fe was reduced, and $\mathrm{K}$ contents increased under moisture stress condition both in straw and grain. In case of $\mathrm{Zn}$ content increase was noted in straw and decrease in grain due to water stress. No clear-cut effect of water stress was seen on Mn content under water stress in both straw and grain. However, moisture stress tolerant wheat genotypes showed lesser alteration in nutrient content than the susceptible genotypes, maintaining optimum nutrient levels in straw and grains.
\end{abstract}

\section{Introduction}

Drought is a significant limiting factor for agricultural productivity and quit enough to inhibit plant growth through declined water absorption and nutrient uptake. Plant mineral nutrition is critical to plant growth and development and has direct implications 
in agriculture and human health too. Drought stress may involve accumulation of mineral elements in plant tissues by changing the pattern of root growth, nutrient mobility in soil and nutrient uptake (Fageria et al., 2002; Samarah et al., 2004). Declined water availability under drought generally results in reduced total nutrient uptake and frequently reduced concentrations of individual mineral nutrients in crop plants (Gunes et al., 2007). The most important effects of water deficits are on transport of nutrients to the root and on root growth and extension. Reduced absorption of inorganic nutrients results from interference with nutrient uptake, unloading mechanisms and reduced transpiration flow (Marschner 1995; Baligar et al., 2001).

In the line of crop nutrition, Potassium is considered one of the necessary elements for the complete function of plants especially for $\mathrm{N}$ and carbohydrate metabolism, activation of various enzymes and adjustment of stomatal movement and water relations. Potassium ions may act together with sugar and other inorganic and organic ions as osmoticadjustment substances. In this concern, Thalooth et al., (1990) found that potassium fertilization may increase plant resistance against unfavourable conditions. In addition, Alderfasi (2009) reported that potassium fertilizer is necessary for high yielding production of wheat under arid condition.

Wheat (Triticum spp.) is one of the major staple food crops in many parts of the world in terms of cultivated area and food source, contributing $28 \%$ of the world edible dry matter (DM) and up to $60 \%$ of the daily calorie intake in most of the developing countries (FAO 2006). Therefore, the biocomposition and nutritional quality of the wheat grain has a significant impact on human health and well-being, especially in the developing countries. Micronutrient malnutrition, and particularly deficiency in
$\mathrm{Zn}, \mathrm{Mn}$ and $\mathrm{Fe}$, victimise over three billion people worldwide (Bouis, 2007; Peleg et al., 2008), resulting in overall poor health, anemia, increased morbidity and mortality rates, and lower workers efficiency (Hotz and Brown 2004). Producing micronutrient enriched cereals (biofortification), either agronomically or genetically, and improving their bioavailability are considered promising and cost-effective approaches for eradicating malnutrition (Ghandilyan et al., 2006; Distelfeld et al., 2007). This solution, however, requires a comprehensive exploitation of potential genetic resources and an in-depth understanding of their micronutrient accumulation mechanisms. Differences can be attributed to plant type, plant tissue, moisture stress level, growing conditions and the duration of the study. Moisture stress stimulates as well as inhibits the uptake of some micronutrients by crop plants at differential organ. In order to better understanding of the mechanisms of nutrient partitioning and alteration of nutrient accumulation between straw and grain under water stress and its differential pattern in tolerant and susceptible wheat genotypes this experiment was conducted with eight wheat genotypes (4 susceptible and 4 tolerant).

\section{Materials and Methods}

\section{Plant material and treatments}

An experiment was conducted in the pot culture, Division of Plant Physiology, Indian Agricultural Research Institute, Pusa, New Delhi, India with 8 wheat genotypes viz. C 306, HD 2987, HD 3016, NI 3039 (tolerant to moisture stress) (Kumari et al., 2014), and PBW 343, HD 2733, PBW 373 and HD 2967 (susceptible to moisture stress) (Kumari et al., 2014) sown in $30 \mathrm{~cm}$ earthen pots of uniform size $(30 \times 30 \mathrm{~cm})$ and filled with $10 \mathrm{~kg}$ mixture of air dried soil and farm yard manure in 3:1 ratio during the winter seasons of 2011-12. 
Nitrogen, phosphorus and potash fertilizers were applied at the rate of 60:60: $60 \mathrm{~kg}$ per hectare respectively in the form of urea, single super phosphate and muriate of potash at the time of sowing. Remaining $60 \mathrm{~kg} \mathrm{~N} \mathrm{ha}^{-1}$ was given at the completion of 25 days of sowing. Moisture stress treatment to plants was given at anthesis through withdrawal of water. Measurement of water stress was done through tensiometer. A calibration curve was made with the help of pressure Fig. apparatus at different pressure from 0 to 15 bars for the same soil and farm yard mixture. One bar soil pressure condition, which is nearly $67-70 \%$ moisture of field capacity, was optimized for taking plant samples. Soil moisture status of pots subjected to stress treatment was maintained throughout the grain growth period. Schedule routine of irrigation was practiced for control plants throughout the crop growth period. Each treatment was replicated 20 times in the form of pots for all the genotypes.

\section{Sample collection}

Straw and grains were sampled for recording observations at harvest stage. For each genotype samples were collected in triplicate from 3 pots. Plant materials were dried in an oven at $60^{\circ} \mathrm{C}$ and ground to fine powder in a grinding machine.

\section{Yield Parameters}

1000-grain weight (g) and harvest index were recorded in control and treated plants at the time of harvest.

\section{Estimation of macro and micronutrients (Potassium, iron, copper, zinc and manganese)}

A representative ground plant sample $(0.5 \mathrm{~g})$ was digested in a di-acid mixture $(20 \mathrm{ml})$ containing $\mathrm{HNO}_{3}$ and $\mathrm{HClO}_{4}$ acid $(9: 4)$ on digestion unit (Gerhardt Turbotherm). After digestion the volume was made $50 \mathrm{ml}$. Potassium was estimated using Flame Photometer (Elico, CL-361). The micro nutrients content ( $\mathrm{Fe}, \mathrm{Zn}$ and $\mathrm{Mn}$ ) in samples were estimated using Atomic Absorption Spectrophotometer (Perkil Elmer, AAnalyst 200). By plotting standard curves with the known concentration of $\mathrm{Fe}, \mathrm{Zn}$, and $\mathrm{Mn}$; the content of $\mathrm{K}, \mathrm{Fe}, \mathrm{Zn}$, and $\mathrm{Mn}$ were calculated in straw and grain samples of wheat genotypes.

\section{Statistical analyses}

The data obtained was subjected to analysis of variance appropriate to the experimental design. F-test was carried out to test the significance of the treatment differences and the least significant difference (LSD) was computed to test the significance of different treatments at $5 \%$ level of probability by the SPSS 10.0.

\section{Results and Discussion}

\section{Harvest index}

Results on the effect of moisture stress on the harvest index of wheat genotypes are shown in Table 1. Mean reduction in harvest index was about 23\%. In case of genotypes C 306, HD 2987, HD 3016 and NI 5439 reductions were very minute, 2 to $5 \%$. But in genotypes PBW 343, HD 2733, PBW 373 and HD 2967 yield reductions were very high, which varied from 28 to $49 \%$.

\section{0 grain weight}

Results on 1000 grain weight of wheat genotypes under moisture stress condition are reported in Table 1. Test weight (1000 grain weight) of seeds decreased significantly under water stress in all genotypes. Genotypes C 306, HD 2987, HD 3016 and NI 5439 showed 
lesser reductions in test weight, which varied from $13-29 \%$, while in case of PBW 343, HD 2733, PBW 373 and HD 2967, it varied from $25-44 \%$.

\section{Potassium content}

The data on the effect of moisture stress treatment on potassium content in the grains and straw of different wheat genotypes are presented in Table 2. The data showed that there was increase in potassium content both in straw and grains in all the genotypes under moisture stress treatment as compared to control. However, potassium content was higher in straw as compared to grain, both under control and moisture stress condition. Overall enhancement in potassium content due to moisture stress was 47 to $76 \%$ in grains of tolerant genotypes and 19 to $39 \%$ in that of moisture stress susceptible wheat genotypes. The increase in potassium content was 44 to $87 \%$ in straw of tolerant genotypes and 14 to $36 \%$ in that of moisture stress susceptible wheat genotypes.

\section{Zinc content}

The data on the effect of moisture stress treatment on zinc content in the grains and straw of different wheat genotypes are presented in Table 3. The data showed that there was increase in zinc content in straw and decline in zinc content of grains in all the genotypes under moisture stress treatment as compared to control. When comparison of grain and straw $\mathrm{Zn}$ content was done, it was found that potassium content was higher in grain under control condition and more in straw under water stress condition, both under control and moisture stress condition. Overall decline in zinc content due to moisture stress was 5 to $17 \%$ in grains of tolerant genotypes and 16 to $27 \%$ in that of moisture stress susceptible wheat genotypes. The increase in zinc content was 44 to $83 \%$ in straw of tolerant genotypes and 28 to $42 \%$ in that of moisture stress susceptible wheat genotypes.

\section{Iron content}

The data on the effect of moisture stress treatment on iron content in the grains and straw of different wheat genotypes are presented in Table 4. The data showed that there was decline in iron content in straw and grains of all the genotypes under moisture stress treatment as compared to control. However, iron content was higher in straw as compared to grain, both under control and moisture stress condition. Overall decline in iron content due to moisture stress was 12 to $17 \%$ in grains of tolerant genotypes and 24 to $62 \%$ in that of moisture stress susceptible wheat genotypes. The decline in iron content was 8 to $39 \%$ in straw of tolerant genotypes and 39 to $83 \%$ in that of moisture stress susceptible wheat genotypes.

\section{Manganese content}

The data on the effect of moisture stress treatment on manganese content in the grains and straw of different wheat genotypes are presented in Table 5. The data showed that there was no clear-cut effect of moisture stress on Mn content under water stress in both straw and grains. In some genotypes manganese content was increasing, while in some genotypes it was decreasing due to moisture stress, both in the case of straw and grains. However, manganese content was higher in straw as compared to grain, both under control and moisture stress condition.

Availability of water is one of the critical factors determining plant distribution and survival in different natural ecosystems. During the past many decades, the primary objective of plant breeding programs has been to increase yield, a subject that will remain a principal concern in providing the calorie 
intake required for the increasing world population. However, equally important, but largely overlooked in breeding programs, is the nutrient composition and concentration, particularly the micronutrients, in the straw and grains of staple food crops (Welch and Graham, 1999; Cakmak, 2002). Breeding programs directed towards increased yield have narrowed the genetic basis of modern crop plants. Therefore, it is essential and urgent to exploit genetic resources from relatives of wheat which harbour a richness of desirable genes (Peleg et al., 2008). Scarcity of water is a drastic environmental constraint to plant productivity. Drought-induced loss in crop yield probably exceeds losses from all other causes, since both the severity and duration of the stress are critical (Farooq et al., 2009).

The present study revealed that water stress affects various yield parameters like harvest index and test weight; as well as potassium and micro nutrient content both in straw and grain. Similar result was reported Kumari et al., (2014) for yield parameters and by Gunes et al., (2007) for micronutrient status in case of wheat under moisture stress treatment. Moisture stress has drastic effect on these parameters, but tolerant genotypes have shown lesser alteration in nutrient accumulation and portioning of it between straw and grains in wheat genotypes.

Drought stress leads to hastened maturity and there will be disturbed nutrient uptake efficiency and photosynthate translocation in the plant that produces shrivelled kernels with decreased 1000 kernel weight (Riaz and Chowdhry, 2003; Kumari et al., 2014). It turns into decline in harvest index and test weight of grains in wheat genotypes. Under such circumstances, a genotype that can mobilize reserves of carbohydrates from the stem and mineral nutrients into stem and grain will be able to maintain better seed filling.
Drought tolerant genotypes show lesser decline in yield and yield components as compared to susceptible wheat genotypes (Kumari et al., 2014).

Potassium was more in straw as compared to grains both in control and moisture stress condition. Under water stress condition its concentration was increased both in straw and grain as compared to control. Potassium accumulation in plant parts is positively correlated with stimulation in root growth and hence, efficient exploration of soil water (Saxena, 1985). Further, it decreases the loss of soil moisture by decreasing the transpiration and increasing the water retention in plants (Umar and Moinuddin, 2002). Potassium ions may act together with sugar and other inorganic and organic ions as osmotic-adjustment substances. Under waterdeficit conditions, $\mathrm{K}$ fertilization enhances crop tolerance to water stress by utilizing the soil moisture more effectively than in $\mathrm{K}$ deficient plants.

This is the cause for increased $\mathrm{K}$ content in grain and straw in wheat genotypes under water stress in our experiments. The positive effects of $\mathrm{K}$ on water stress tolerance may be through promotion of root growth accompanied by a greater uptake of other nutrients and water by plants (Rama Rao, 1986) and through the reduction of transpirational water loss (Beringer and Trolldenier, 1978), is the explanation of higher increase in $\mathrm{K}$ content in grain and straw of moisture stress tolerant wheat genotypes under drought compared to susceptible in our investigation. Also, K maintains the osmotic potential and turgor of the cells (Hsio, 1973; Lindhauer, 1985) and regulates the stomatal functioning under water stress conditions (Kant and Kafkafi, 2002), which is reflected in improved crop yield in drought conditions (Umar and Bansal, 1995; Umar and Moinuddin, 2002). 
Table.1 Effect of moisture stress on harvest index and test weight in wheat genotypes

\begin{tabular}{|c|c|c|c|c|c|c|}
\hline \multirow[t]{2}{*}{ Genotype } & \multicolumn{3}{|c|}{ Harvest index (\%) } & \multicolumn{3}{|c|}{1000 grain weight (g) } \\
\hline & Control & Moisture stress & $\%$ Decrease & Control & Moisture stress & $\%$ Decrease \\
\hline C 306 & 38.50 & 37.40 & 2.86 & 46.15 & 38.35 & 16.90 \\
\hline HD 3016 & 45.19 & 33.07 & 26.83 & 45.98 & 36.75 & 20.07 \\
\hline NI 5439 & 43.24 & 40.88 & 5.46 & 42.55 & 29.88 & 29.79 \\
\hline HD 2733 & 37.61 & 27.08 & 27.98 & 52.25 & 36.30 & 30.53 \\
\hline PBW 373 & 42.23 & 21.64 & 48.75 & 46.35 & 34.35 & 25.89 \\
\hline HD 2967 & 42.19 & 25.39 & 39.82 & 43.69 & 30.50 & 30.19 \\
\hline Mean & 41.17 & 31.42 & & 46.19 & 33.86 & \\
\hline \multicolumn{7}{|l|}{ CD at $5 \%$} \\
\hline Treatment (T) & & 0.022 & & & 0.789 & \\
\hline Variety (V) & & 0.044 & & & 1.577 & \\
\hline $\mathbf{T} \times \mathbf{V}$ & & 0.063 & & & 2.231 & \\
\hline
\end{tabular}

Table.2 Effect of moisture stress on $\mathrm{K}$ content $(\%)$ in grain and straw in wheat genotypes

\begin{tabular}{|c|c|c|c|c|c|c|c|}
\hline \multirow[t]{2}{*}{ Genotype } & \multicolumn{4}{|c|}{$\mathrm{K}$ content in grains $(\%)$} & \multicolumn{3}{|c|}{$\mathrm{K}$ content in straw $(\%)$} \\
\hline & Control & Moisture stress & \multicolumn{2}{|c|}{ \% Decrease } & Control & Moisture stress & $\%$ Decrease \\
\hline C 306 & 0.45 & 0.79 & 75.6 & & 1.20 & 1.92 & 60.0 \\
\hline HD 2987 & 0.39 & 0.66 & 71.6 & & 1.06 & 1.52 & 43.7 \\
\hline HD 3016 & 0.32 & 0.48 & 48.1 & & 0.95 & 1.78 & 87.1 \\
\hline NI 5439 & 0.40 & 0.59 & 47.1 & & 0.78 & 1.35 & 73.1 \\
\hline HD 2733 & 0.39 & 0.54 & 39.0 & & 0.82 & 0.93 & 14.2 \\
\hline PBW 343 & 0.40 & 0.54 & 37.2 & & 0.87 & 1.13 & 29.9 \\
\hline PBW 373 & 0.42 & 0.51 & 22.9 & & 1.00 & 1.33 & 33.0 \\
\hline HD 2967 & 0.38 & 0.45 & 19.1 & & 0.77 & 1.04 & 35.9 \\
\hline \multirow[t]{2}{*}{ Mean } & 0.39 & 0.57 & & & 0.93 & 1.38 & \\
\hline & Plant part (P) & Treatments $(\mathrm{T})$ & PXT & Genotypes (G) & P X G & T X G & P X T X G \\
\hline SEm \pm & 0.01 & 0.01 & 0.015 & 0.021 & 0.029 & 0.029 & 0.041 \\
\hline LSD $(P \leq 0.05)$ & 0.029 & 0.029 & 0.041 & 0.058 & 0.082 & 0.082 & 0.116 \\
\hline
\end{tabular}


Table.3 Effect of moisture stress on $\mathrm{Zn}$ content ( $\mathrm{ppm}$ ) in grain and straw in wheat genotypes

\begin{tabular}{|c|c|c|c|c|c|c|c|c|}
\hline \multirow[t]{2}{*}{ Genotype } & \multicolumn{4}{|c|}{$\begin{array}{l}\text { Zn content in grains } \\
(\mathbf{p p m})\end{array}$} & & \multicolumn{3}{|c|}{$\begin{array}{c}\text { Zn content in straw } \\
(\mathbf{p p m})\end{array}$} \\
\hline & Control & Moisture stress & \multicolumn{2}{|c|}{ \% Decrease } & & Control & Moisture stress & $\%$ Increase \\
\hline C 306 & 31.8 & 26.3 & \multicolumn{2}{|c|}{17.3} & & 27.5 & 50.2 & 82.5 \\
\hline HD 2987 & 31.7 & 28.1 & \multicolumn{2}{|l|}{11.4} & & 21.6 & 37.0 & 71.3 \\
\hline HD 3016 & 22.2 & 19.8 & \multicolumn{2}{|l|}{10.8} & & 24.0 & 37.0 & 54.2 \\
\hline NI 5439 & 27.3 & 25.8 & \multicolumn{2}{|l|}{5.3} & & 20.9 & 33.3 & 59.3 \\
\hline HD 2733 & 28.8 & 23.7 & \multicolumn{2}{|l|}{17.8} & & 26.5 & 37.7 & 42.3 \\
\hline PBW 343 & 30.4 & 24.2 & \multicolumn{2}{|l|}{20.4} & & 22.4 & 31.3 & 39.7 \\
\hline PBW 373 & 26.4 & 19.4 & \multicolumn{2}{|l|}{26.5} & & 21.9 & 29.9 & 36.5 \\
\hline HD 2967 & 26.8 & 22.4 & \multicolumn{2}{|l|}{16.4} & & 26.4 & 33.9 & 28.4 \\
\hline \multirow[t]{2}{*}{ Mean } & 28.18 & 23.72 & & & & 23.90 & 36.18 & \\
\hline & Plant part (P) & Treatments (T) & PXT & Genc & es $(G)$ & P X G & T X G & PX T X G \\
\hline SEm \pm & 0.198 & 0.198 & 0.28 & & 0.395 & 0.559 & 0.559 & 0.791 \\
\hline LSD $(P \leq 0.05)$ & 0.559 & 0.559 & 0.79 & & 1.117 & 1.58 & 1.58 & 2.235 \\
\hline
\end{tabular}


Table.4 Effect of moisture stress on Fe content (ppm) in grain and straw in wheat genotypes

\begin{tabular}{|c|c|c|c|c|c|c|c|}
\hline \multirow[t]{2}{*}{ Genotype } & \multicolumn{4}{|c|}{$\begin{array}{c}\text { Fe content in grains } \\
(\text { ppm) }\end{array}$} & \multicolumn{3}{|c|}{$\begin{array}{c}\text { Fe content in straw } \\
(\mathbf{p p m})\end{array}$} \\
\hline & Control & Moisture stress & \multicolumn{2}{|c|}{$\%$ Decrease } & Control & Moisture stress & $\%$ Decrease \\
\hline C 306 & 92.6 & 81.4 & \multicolumn{2}{|l|}{12.1} & 617.90 & 569.8 & 7.8 \\
\hline HD 2987 & 85.6 & 70.9 & \multicolumn{2}{|l|}{17.2} & 674.50 & 495.7 & 26.5 \\
\hline HD 3016 & 113.1 & 98.6 & \multicolumn{2}{|l|}{12.8} & 802.3 & 491.0 & 38.8 \\
\hline NI 5439 & 99.5 & 84.7 & \multicolumn{2}{|l|}{14.9} & 849.6 & 569.1 & 33.0 \\
\hline HD 2733 & 109.3 & 72.6 & \multicolumn{2}{|l|}{33.6} & 786.00 & 443.4 & 43.6 \\
\hline PBW 343 & 95.7 & 64.9 & \multicolumn{2}{|l|}{32.2} & 846.70 & 456.6 & 46.1 \\
\hline PBW 373 & 178.1 & 67.6 & \multicolumn{2}{|l|}{62.0} & 953.4 & 581.3 & 39.0 \\
\hline HD 2967 & 109.4 & 83.2 & \multicolumn{2}{|l|}{23.9} & 746.9 & 124.4 & 83.3 \\
\hline \multirow[t]{2}{*}{ Mean } & 110.41 & 77.99 & & & 784.66 & 466.42 & \\
\hline & Plant part (P) & Treatments (T) & PXT & Genotypes (G) & PX G & TX G & PX T X G \\
\hline SEm \pm & 0.397 & 0.397 & 0.562 & 0.795 & 1.124 & 1.124 & 1.590 \\
\hline $\mathrm{LSD}(\mathrm{P} \leq \mathbf{0 . 0 5})$ & 1.123 & 1.123 & 1.588 & 2.246 & 3.176 & 3.176 & 4.492 \\
\hline
\end{tabular}


Table.5 Effect of moisture stress on Mn content (ppm) in grain and straw in wheat genotypes

\begin{tabular}{|c|c|c|c|c|c|c|c|}
\hline \multirow[t]{2}{*}{ Genotype } & \multicolumn{4}{|c|}{$\begin{array}{l}\text { Mn content in grains } \\
\text { (ppm) }\end{array}$} & \multicolumn{3}{|c|}{$\begin{array}{l}\text { Mn content in straw } \\
(\mathbf{p p m})\end{array}$} \\
\hline & Control & Moisture stress & \multicolumn{2}{|c|}{$\begin{array}{l}\text { \% Decrease } \\
\text { /Increase }\end{array}$} & Control & Moisture stress & $\begin{array}{l}\text { \% Decrease } \\
\text { /Increase }\end{array}$ \\
\hline C 306 & 29.3 & 23.2 & \multicolumn{2}{|c|}{-20.8} & 26.0 & 41.0 & 57.7 \\
\hline HD 2987 & 18.4 & 29.0 & \multicolumn{2}{|l|}{57.6} & 32.5 & 38.4 & 18.2 \\
\hline HD 3016 & 36.3 & 33.8 & \multicolumn{2}{|l|}{-6.9} & 40.8 & 36.3 & -11.0 \\
\hline NI 5439 & 24.1 & 28.4 & \multicolumn{2}{|l|}{17.8} & 38.5 & 35.8 & -7.0 \\
\hline HD 2733 & 24.2 & 33.2 & \multicolumn{2}{|l|}{37.2} & 28.5 & 37.8 & 32.6 \\
\hline PBW 343 & 20.9 & 21.5 & \multicolumn{2}{|l|}{2.9} & 34.8 & 33.8 & -2.9 \\
\hline PBW 373 & 26.4 & 25.2 & \multicolumn{2}{|l|}{-4.5} & 48.8 & 42.7 & -12.5 \\
\hline HD 2967 & 35.6 & 27.1 & \multicolumn{2}{|l|}{-23.9} & 35.3 & 25.7 & -27.2 \\
\hline \multirow[t]{2}{*}{ Mean } & 27.04 & 27.69 & & & 35.64 & 36.46 & \\
\hline & Plant part (P) & Treatments (T) & PXT & Genotypes (G) & P X G & T X G & P X T X G \\
\hline SEm \pm & 0.291 & 0.291 & 0.412 & 0.582 & 0.823 & 0.823 & 1.165 \\
\hline LSD $(P \leq 0.05)$ & 0.823 & N/A & N/A & 1.645 & 2.327 & 2.327 & 3.291 \\
\hline
\end{tabular}

Note: In \% Decrease/Increase column -ve value shows decline in Mn content, while +ve value shows increase in Mn content. 
Besides, it takes part in many essential processes in plants (Marschner, 1995) and enhances photosynthetic rate, plant growth and yield under stress conditions (Egila et al., 2001; Umar and Moinuddin, 2002). As per Cakmak (1997), the protective role of $\mathrm{K}$ in plants suffering from drought stress has been attributed to the maintenance of a high $\mathrm{pH}$ in stroma and in oppose to the photo-oxidative damage to chloroplasts.

Two major micro nutrients i.e. iron, and zinc contents were severely reduced by moisture stress in wheat straw. In grain iron increased, while zinc decreased under moisture stress. The reductions were relatively lesser in case of the tolerant genotypes; similarly increase in accumulation was comparatively more in tolerant genotypes as compared to susceptible. Alderfasi and Alghamdi (2010) also reported moisture stress induced decrease in Fe content in case of faba beans straw. It is noticeable that $\mathrm{Mn}$ concentration had no definite trend under control and water stress, both in case of straw and grains.

Whole plant senescence in monocarpic plants such as wheat (Triticum aestivum L.) is the final stage of growth and development (Nooden et al., 1997). It is a genetically programmed process that involves remobilization of nutrients among vegetative tissues and grains (Nooden, et al., 1997; Ori et al., 1999). But this remobilization got disturbed under moisture stress condition. Same is noted in our investigation that moistute stress either increase or decrease $\mathrm{K}$, $\mathrm{Zn}$ and $\mathrm{Fe}$ accumulation in straw and grains, which is the outcome of disturbed mineral nutrient portioning among vegetative and reproductive plant parts. But moisture stress tolerant genotypes have shown less alteration in mineral nutrient partitioning among various plant parts as compared to susceptible wheat genotypes.
From the above results, it can be concluded that moisture stress results in nutrient imbalances by affecting nutrient uptake, availability and partitioning within the plant and among various plant parts. Moisture stress tolerant genotypes, which effectively maintained nutrient concentration could tolerate moisture stress by maintaining nutrient levels within the optimum level. Moisture stress susceptible wheat genotypes showed severe nutrient imbalances like reduced contents of magnesium, manganese, and iron and increased levels of potassium. Moisture stress tolerant performed better most probably due to its capacity to maintain higher relative water content in root and other plant tissues, thus alleviate the ill effect of moisture stress on ion uptake and partitioning.

\section{Acknowledgement}

Authors acknowledge DST INSPIRE fellowship, Govt. of India for funding of research.

\section{References}

Alderfasi, A.A. and Alghamdi, S.S. 2010. Integrated Water Supply with Nutrient Requirements on Growth, Photosynthesis Productivity, Chemical Status and Seed Yield of Faba Bean. American-Eurasian Journal of Agronomy, 3(1): 08-17.

Alderfasi, A.A. 2009. Integrated use of potassium fertilizer and water schedules on growth and yield of two wheat genotypes under Arid Environ. Saudi Arabia. I) Effect on yield and yield component characters. World J. Agric. Sci., 5(2): 221-227.

Baligar, V.C., Fageria, N.K. and He, Z.L. 2001. Nutrient use efficiency in plants. Comm. Soil Sci Plant Anal 32:921-950.

Beringer, H. and Trolldenier, G. 1978. Influence of $\mathrm{K}$ nutrition on the response 
to environmental stresses. In: Potassium Research - Reviews and Trends". International Potash Institute, Basel, Switzerland, pp. 189-222.

Bouis, H.E. 2007. The potential of genetically modified food crops to improve human nutrition in developing countries. J Dev Stud 43:79-96.

Cakmak, I., Graham, R. and Welch, R.M. 2002. Agricultural and molecular genetic approaches to improving nutrition and preventing micronutrient malnutrition globally. In: Cakmak I, Welch RM (eds) Encyclopaedia of life support systems. Eolss, Oxford, pp 1075-1099.

Cakmak, I. 1997. Role of potassium in protecting higher plants against photooxidative damage. In: Johnston, A.E. (Ed.), Food security in the WANA region, the essential need for balanced fertilization, International Potash Institute, Basel Switzerland, pp. 345352.

Distelfeld, A., Cakmak. I., Peleg. Z., Ozturk, L., Yazici, A.M., Budak, H., Saranga, Y. and Fahima, T. 2007. Multiple QTLeffects of wheat Gpc-B1 locus on grain protein and micronutrient concentrations. Physiol Plant 129:635643.

Egila, J.N., Davies, F.T.Jr., and Drew, M.C. 2001. Effect of potassium on drought resistance of Hibiscus rosa-sinensis cv. Leprechaun: plant growth, leaf macro and micronutrient content and root longevity. Plant Soil, 229: 213-224.

Fageria, N.K., Baligar, V.C. and Clark, R.B. 2002. Micronutrients in crop production. Adv Agron 77:185-267.

FAO 2006. The Statistics Division, United Nations, Rome, 2006.

Farooq, M., Wahid, A., Kobayashi, N., Fujita, D. and Basra, S.M.A. 2009. Plant Drought Stress: Effects, Mechanisms and Management. In: Lichtfouse E.,
Navarrete M., Debaeke P., Véronique S., Alberola C. (eds) Sustainable Agriculture. Springer, Dordrecht.

Ghandilyan, A., Vreugdenhil, D., Aarts, M.G.M. 2006. Progress in the genetic understanding of plant iron and zinc nutrition. Physiol Plant 126:407-417.

Gunes, A., Inal, A., Adak, M.S., Alpaslan, M., Bagci, E.G., Erol, T., Pilbeam, D.J. 2007. Mineral nutrition of wheat, chickpea and lentil as affected by mixed cropping and soil moisture. Nutr Cycl Agroecosyst, 78: 83-96.

Hotz, C. and Brown, K.H. 2004. Assessment of the risk of zinc deficiency in populations and options for its control. Food Nutr Bull 25:94-204.

Hsio, T.C. 1973. Plant responses to water stress. Ann. Rev. Plant Physiol., 24: 519-570.

Kant, S. and Kafkafi, U. 2002. Potassium and Abiotic Stresses in Plants. Pasricha, N. S., Bansal, S.K. (Eds.), Role of potassium in nutrient management for sustainable crop production in India, Potash Research Institute of India, Gurgaon, Haryana.

Kumari, A., Sairam, R.K. and Singh, S.K. 2014. Effect on physiological, growth and yield parameters of wheat genotypes under drought stress. Int. J. Agricult. Stat. Sci. Vol. 10(1): 167-174.

Lindhauer, M.G. 1985. Influence of K nutrition and drought and water stressed sunflower plants differing in $\mathrm{K}$ nutrition. J. Plant Nutr., 10: 1965-1973.

Marschner, H. 1995. Mineral nutrition of higher plants, 2nd edn. Academic Press, London.

Nooden, L.D., Guiamet, J.J. and John, I. 1997. Senescence mechanisms. Physiologia Plantarum., 101: 746-753.

Ori, N., Juarez, M.T., Jackson, D., Yamaguchi, D. and Banowetz, G.M. 1999. Leaf senescence is delayed in tobacco plants expressing the maize 
homeobox gene knotted1 under the control of a senescence- activated promoter. Plant Cell., 11: 1073-1080.

Peleg, Z., Saranga, Y., Yazici, A., Fahima, T., Ozturk, L. and Cakmak, I. 2008. Grain zinc, iron and protein concentrations and zinc-efficiency in wild emmer wheat under contrasting irrigation regimes. Plant Soil, 306:57-67.

Rama Rao, N. 1986. Potassium nutrition of pearl millet subjected to moisture stress. J. Potassium Res., 2: 1-12.

Riaz, R. and Chowdhry, M. 2003. Genetic analysis of some economic traits of wheat under drought condition. Asian J. Plant Sci., 2: 790-796.

Samarah, N., Mullen, R. and Cianzio, S. 2004. Size distribution and mineral nutrients of soybean seeds in response to drought stress. J. Plant Nutr., 27:815835.

Saxena, N.P. (1985). The role of potassium in drought tolerance, Potash review, No. 5, International Potash Institute, Bern. 16: $1-15$.

Thalooth, A.T., El-Zeiny, H.A. and Saad, A.O.M. 1990. Application of potassium fertilizer for increasing salt tolerance of broad bean (Vicia faba L.) Bull. Egypt. Soc. Physiol. Sci., 10(3): 181-198.

Umar, S. and Moinuddin. 2002. Genotypic differences in yield and quality of groundnut as affected by potassium nutrition under erratic rainfall conditions. J. Plant Nutr., 25: 15491562.

Umar, S. and Bansal, S.K. 1995. Potassium requirement of mustard under moisture stress condition. J. Plant Physiol. Biochem., 22: 130-135.

Welch, R.M. and Graham, R.D. 1999. New paradigm for world agriculture: meeting human needs. Productive, sustainable nutritious. Field Crops Res., 60: 1-10.

\section{How to cite this article:}

Aradhna Kumari, R.K. Sairam and Santosh Kumar Singh. 2019. Nutrient Content in Grain and Straw of Different Wheat Genotypes as Affected by Moisture Stress. Int.J.Curr.Microbiol.App.Sci. 8(02): 1977-1988. doi: https://doi.org/10.20546/ijcmas.2019.802.232 